\title{
FAKTOR-FAKTOR PENYEBAB TERJADINYA PENCEMARAN AIR DI SUNGAI BINDU
}

\author{
I Wayan Eka Artajaya ${ }^{1)}$, Ni Kadek Felyanita Purnama Putri ${ }^{2)}$ \\ 1)2)Universitas Mahasaraswati Denpasar \\ Email : ekaartajaya@unmas.ac.id ${ }^{1}$
}

\begin{abstract}
Indonesia is a very large and wide country, consisting of many islands and abundant natural resources. Natural resources in Indonesia are everything that comes from nature that is used to meet the needs of human life. Generally, natural resources in Indonesia can be classified based on their nature, namely renewable natural resources and non-renewable natural resources. Humans are very dependent on natural resources and the sustainability of natural resources is strongly influenced by human activities. Watershed is one of the natural resources that is very complex and consists of various components that make it up. The functions and benefits of water resources themselves, including rivers, require various efforts to improve and protect water so that it is efficient and effective for living things and the surrounding environment. One of them is the Bindu river in the Kesiman Traditional Village. The Bindu River is widely used by the community, causing water pollution in the Bindu river, such as the Kesiman Traditional Village which has an important role in suppressing the occurrence of water pollution that occurs in the Bindu river.
\end{abstract}

Keywords: Water Pollution, Role, Kesiman Traditional Village

\begin{abstract}
Abstrak
Negara Indonesia merupakan negara yang sangat besar dan luas, terdiri dari banyak pulau dan sumber daya alam yang melimpah. Sumber daya alam di Indonesia merupakan segala sesuatu yang berasal dari alam yang digunakan untuk memenuhi kebutuhan hidup manusia. Umumnya sumber daya alam di Indonesia dapat digolongkan berdasarkan sifatnya yaitu sumber daya alam yang dapat diperbaharui dan sumber daya alam yang tidak dapat diperbaharui. Manusia sangat bergantung pada sumber daya alam dan kelestarian sumber daya alam sangat dipengaruhi oleh aktivitas manusia. Daerah aliran sungai merupakan salah satu sumber daya alam yang sangat kompleks dan terdiri dari berbagai komponen yang menyusunnya. Fungsi dan manfaat sumber daya air sendiri termasuk sungai memerlukan berbagai upaya untuk peningkatan dan perlindungan air agar berdaya guna dan berhasil guna bagi makhluk hidup dan lingkungan sekitar. Salah satunya adalah sungai Bindu yang berada di Desa Adat Kesiman. Sungai Bindu banyak dimanfaatkan oleh masyarakat sehingga menyebabkan terjadinya pencemaran air di sungai Bindu, seperti Desa Adat Kesiman memiliki peranan penting dalam menekan terjadinya pencemaran air yang terjadi di sungai Bindu.
\end{abstract}


Kata Kunci : Pencemaran Air, Peranan, Desa Adat Kesiman

\section{A. Pendahuluan}

Negara Indonesia merupakan negara yang sangat besar dan luas, yang terdiri dari banyaknya pulau dan memiliki sumber daya alam yang sangat melimpah yang sebagai Anugerah Tuhan Yang Maha Esa. ${ }^{1}$ Sunber daya alam di Indonesia adalah segala sesuatu yang berasal dari alam yang dapat digunakan untuk memenuhi kebutuhan hidup manusia. Pada umumnya sumber daya alam di Indonesia dapat digolongkan berdasarkan sifatnya yaitu sumber daya alam yang dapat diperbaharui dan sumber daya alam yang tidak dapat diperbaharui. $^{2}$ Tekanan terhadap sumber daya alam sangat besar seiring dengan tuntutan manusia untuk memenuhi kebutuhan hidupnya. Dalam proses pembangunan manusia sangat berperan aktif dalam proses pemanfaatan sumber daya alam. Manusia sangat bergantung pada sumber daya alam dan kelestarian

\footnotetext{
${ }^{1}$ Susriman, Prosiding Seminar Nasional "Tanggung Jawab Pelaku Bisnis dalam Pengelolaan Lingkungan”, Hal. 367.

${ }^{2}$ Wikipedia,https://id.wikipedia.org/wi ki/Sumber_daya_alam, diakses pada tanggal 22 Oktober 2020.
}

sumber daya alam sangat dipengaruhi oleh aktivitas manusia.

Daerah aliran sungai merupakan salah satu sumber daya alam yang sangat kompleks dan terdiri dari berbagai komponen yang menyusunnya. Komponen tersebut terdiri dari berbagai sumber daya vegetasi (hutan), tanah, dan air. Sungai merupakan salah satu sumber daya alam yang bersifat mengalir, sehingga air yang berada di hulu sungai akan bermanfaat di hilir sungai. ${ }^{3}$ Sungai sendiri sangat bermanfaat bagi makhluk hidup lainnya. Sumber daya air yang terdapat disungai merupakan kebutuhan utama yang sangat potensial bagi aktivitas makhluk hidup untuk menjaga proses perkembangan hidupnya. Air yang bersih tentunya sangat didambakan oleh semua makhluk hidup. Kebutuhan air tentutnya tidak bisa lepas dari makhluk hidup. ${ }^{4}$ Air merupakan salah satu

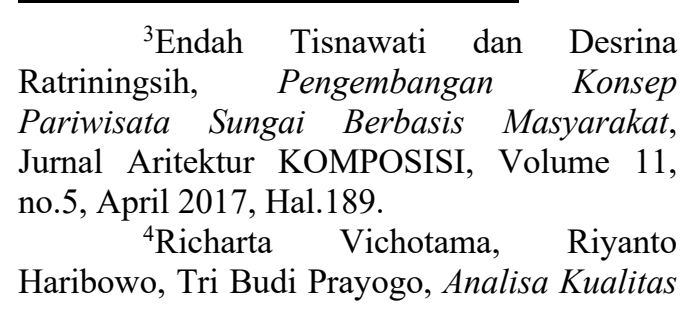


kebutuhan yang paling esensial bagi makhluk hidup. Ketersediaan sumber daya air sangat bervariasi. Fungsi dan manfaat sumber daya air sendiri termasuk sungai memerlukan berbagai upaya untuk peningkatan dan perlindungan air agar berdaya guna dan berhasil guna bagi makhluk hidup dan lingkungan sekitar.

Sejalan dengan berkembangnya zaman, dimana pesatnya pertumbuhan dan peningkatan jumlah penduduk, yang dimana peningkatan tersebut juga mempengaruhi peningkatan kegiatan pembangunan yang membutuhkan banyak air baik di daerah perkotaan atau pedesaan. ${ }^{5}$ Salah satunya yang terdapat di Desa Adat Kesiman. Desa Adat Kesiman merupakan salah satu desa yang terletak di Kota Denpasar, yang berada di timur Kota Denpasar. Desa Adat Kesiman terdiri dari tiga wilayah desa, yaitu Desa Kesiman Kelurahan, Desa Kesiman Petilan, dan Desa Kesiman Kertalangu. Desa Adat

Air Tukad Badung, Denpasar, Bali Menggunakan Program QUAL2Kw, Jurnal Teknologi dan Rekayasa Sumber Daya Air, Volume 1, No.1, 2021, Hal.40-51.

${ }^{5}$ Sulastriyono, Pembangunan Hukum

Sumber Daya Air Sungai Yang Berbasis Kearifan Lokal: Peluang dan Tantangannya, Jurnal Mimbar Hukum, Volume 20, No.3, Oktober 2008, Hal.411-588.
Kesiman ini juga memiliki 31 banjar/dusun. Desa Adat Kesiman memiliki sumber daya alam. Salah satunya adalah Sungai Bindu atau yang lebih dikenal dengan Tukad Bindu. Sungai Bindu ini berlokasi di Banjar Ujung, Kelurahan Kesiman,Kecamatan Denpasar Timur. Sungai Bindu ini merupakan sungai yang mengalir dari hulu ke hilir. Sungai Bindu banyak dimanfaatkan oleh masyarakat Desa Adat Kesiman, terutama masyarakat sekitar Sungai Bindu. Dengan adanya peningkatan jumlah penduduk dan meningkatnya suatu sektor pembangunan di sekitar wilayah Sungai Bindu, menyebabkan terjadinya pencemaran lingkungan khususnya pencemaran air, yang mengakibatkan Sungai Bindu menjadi kotor.

Pemerintah Indonesia telah mengeluarkan Undang-Undang No. 17 Tahun 2019 tentang Sumber Daya Alam yang menimbang bahwa dalam menghadapi ketidakseimbangan antara ketersediaan air yang cenderung menurun dan kebutuhan air yang semakin meningkat, sumber daya air perlu dikelola dengan memperhatikan fungsi sosial, lingkungan hidup, dan ekonomi secara selaras untuk 
Jurnal Hukum Saraswati (JHS),Volume. 03, Nomor 02, (2021)

FAKULTAS HUKUM UNMAS DENPASAR

ISSN (Cetak) : 2715-758X ISSN (Online): 2720-9555

Doi:https://doi.org/10.36733/jhshs.v2i2

https://e-journal.unmas.ac.id/index.php/JHS

mewujudkan sinergi dan keterpaduan antar wilayah, sektor, dan generasi guna memenuhi kebutuhan rakyat. Masalah pencemaran air yang terdapat di Sungai Bindu merupakan fenomena sosial yang perlu mendapatkan pehatian khusus dari semua para pihak, khususnya dari Desa Adat Kesiman sendiri. Pemerintah Provinsi Bali telah mengeluarkan Peraturan Daerah No. 4 Tahun 2005 tentang Pengendalian Pencemaran dan Perusakan Lingkungan Hidup. Di sisi lain, Desa Adat Kesiman juga mengeluarkan suatu peraturan desa atau yang dikenal dengan awig-awig. Awig-awig Desa Adat Kesiman No. 24 mengatur tentang lingkungan desa yang berdasarkan falsafah Tri Hita Karana yang bersumber pada ajaran agama Hindu di Bali, maka kedudukan, fungsi, dan peranan awig-awig tersebut diatur dengan Peraturan Daerah. Tri Hita Karana merupakan tiga penyebab terciptanya kebahagiaan. Tri Hita Karana dibagi menjadi tiga bagian yaitu Parahyangan yaitu hubungan manusia dengan Tuhan/Ida Sang Hyang Widhi, Pawongan yaitu hubungan manusia dengan sesama manusia, dan Palemahan yaitu

\section{5}

hubungan manusia dengan alam sekitar.

Pada penjelasan bagian umum awig-awig Desa Kesiman termuat latar belakang mengapa awig-awig desa ini disusun, yaitu untuk menjaga keasrian dan kelestarian lingkungan Desa Adat Kesiman. Akan tetapi, di dalam awigawig tersebut belum tersurat tentang pencegahan pencemaran air yang terdapat di sungai Bindu, hanya saja baru tersirat tentang hubungan manusia dengan alam atau lingkungan sekitar sungai Bindu. Desa Adat Kesiman juga telah mengeluarkan perarem desa adat yang berisi tentang aturan-aturan perilaku masyarakat yang berkunjung ke Sungai Bindu, seperti larangan membuang sampah atau limbah rumah tangga ke areal Sungai Bindu, dilarang bertingkah laku yang tidak baik di sekitar wilayah Sungai Bindu, dan dilarang menangkap ikan menggunakan racun, setrum listrik, atau sejenisnya di Sungai Bindu. Dalam realisasi yang ada di masyarakat, banyak yang tidak mengedepankan dan tidak menerapkan dengan baik peraturan-peraturan yang diberikan oleh pemerintah atau yang dibuat oleh Desa Adat Kesiman, 
Jurnal Hukum Saraswati (JHS),Volume. 03, Nomor 02, (2021)

FAKULTAS HUKUM UNMAS DENPASAR

ISSN (Cetak) : 2715-758X ISSN (Online): 2720-9555

Doi:https://doi.org/10.36733/jhshs.v2i2

https://e-journal.unmas.ac.id/index.php/JHS

bahkan masih banyak masyarakat Desa

Kesiman yang kurang pengetahuan akan peraturan tersebut. Padahal didalam awig-awig Desa Adat Kesiman telah berisi sanksi-sanksi yang mengatur tentang kerusakan lingkungan di Desa Adat Kesiman. Akan tetapi menurut ketua Bendesa Adat Kesiman masih banyak masyarakat Desa Kesiman yang tidak menghiraukan awig-awig tersebut dan tetap membuang sampah serta limbah di Sungai Bindu, tanpa memikirkan dampak apa yang akan terjadi nantinya.

\section{B. Metode Penelitian}

Dalam penulisan artikel ini penulis menggunakan metode empiris, hal ini dilakukan guna untuk melihat hukum dalam artian nyata dan meneliti bagaimana bekerjanya hukum dilingkungan masyarakat, yang diambil dari fakta-fakta yang ada di dalam suatu masyarakat. Dalam metode penelitian empiris ini, penulis menggunakan beberapa teknik pengumpulan data seperti teknik studi dokumen, teknik wawancara, dan teknik observasi/pengamatan langsung ke lapangan.

\section{Pembahasan}

Dalam Undang-Undang No. 23 Tahun 1997 tentang Pengelolaan Lingkungan Hidup selanjutnya dirubah menjadi Undang-Undang No. 32 Tahun 2009 tentang Perlindungan dan Pengelolaan Lingkungan Hidup dan Peraturan Pemerintah No. 20 Tahun 1990 tentang Pengendalian Pencemaran Air menyebutkan bahwa pencemaran air adalah masuknya/dimasukannya makhluk hidup, zat, atau komponen lain ke dalam air oleh kegiatan manusia itu sendiri, sehingga menyebabkan turunnya fungsi dan kualitas air tersebut.

Peningkatan jumlah penduduk dan perkembangan pembangunan yang terdapat di sekitar wilayah Sungai Bindu sangat berpengaruh terhadap kondisi kualitas dan kuantitas perairan sungai. Pencemaran air yang terjadi di Sungai Bindu akan menurunkan kualitas perairan yang pada akhirnya akan sangat berpengauh terhadap kondisi sekitar lingkungan Sungai Bindu dan kesehatan penduduk yang secara langsung atau tidak langsung memanfaatkan air tersebut. Oleh karena itu, ada Peraturan PerundangUndangan yang mengaturnya di dalam 
Jurnal Hukum Saraswati (JHS),Volume. 03, Nomor 02, (2021)

FAKULTAS HUKUM UNMAS DENPASAR

ISSN (Cetak) : 2715-758X ISSN (Online): 2720-9555

Doi:https://doi.org/10.36733/jhshs.v2i2

https://e-journal.unmas.ac.id/index.php/JHS

127

Peraturan Daerah Provinsi Bali No. 4 Tahun 2005 tentang Pengendalian Pencemaran dan Perusakan

Lingkungan Hidup, yang pada Pasal 5 mengemukakan mengenai :

“1. Setiap orang harus memelihara kelestarian fungsi lingkungan hidup dengan upaya pencegahan, pengawasan, penanggulangan, dan pemulihan kualitas lingkungan akibat pencemaran dan/atau perusakan lingkungan hidup.

Setiap orang yang

2. melakukan usaha yang mengandung potensi pencemaran dan/atau perusakan lingkungan harus memberikan informasi yang benar dan akurat mengenai pengendalian pencemaran dan/atau perusakan lingkungan hidup."

Pencemaran air yang terdapat di Sungai Bindu telah menunjukkan permasalahan yang sangat serius.

Secara umum pencemaran air dapat dikelompokan menjadi 5 yaitu:

1. Pencemaran air yang diakibatkan oleh sampah yang mengandung senyawa organik seperti sampah industri makanan, sampah rumah tangga, kotoran manusia atau hewan.

2. Pencemaram air yang diakibatkan oleh limbah yang mengandung virus/bakteri, seperti limbah rumah tangga, kotoran manusia/hewan.

3. Pencemaran air yang diakibatkan oleh terkontaminasinya senyawa anorganik, seperti mineral atau logam berat.

4. Pencemaran air yang diakibatkan oleh terkontaminasinya senyawa organik, seperti pestisida, detergen, dan limbah minyak.

5. Pencemaran air yang diakibatkan oleh endapan atau sidemen berupa tanah/lumpur akibat erosi.

Dari data hasil wawancara yang telah dilakukan dengan Bapak I Gusti Rai Ari Temaja, S.E selaku Penggagas 
sekaligus bertindak sebagai Pengawas di Yayasan Tukad Bindu diketahui bahwa Sungai Bindu mulai tercemar dari tahun 1990 sampai tahun 2010 sejak dibangunnya ruas Jalan By Pass Gatot Subroto dengan Denpasar. ${ }^{6}$ Selain itu menurut hasil wawancara dengan I Nyoman Artha Wiguna, selaku masyarakat setempat, Sungai Bindu memang sudah tercemar sejak lama, faktor utamanya adalah ulah manusia sendiri yang menjadikan Sungai Bindu sebagai tempat pembuangan sampah atau limbah rumah tangga dengan sembarangan. ${ }^{7}$ Berbagai upaya telah dilakukan oleh Bendesa Adat Kesiman dalam menanggulangi pencemaran air yang terdapat di Sungai Bindu.

Dalam menangani kasus pencemaran air ini, Kepala Lingkungan Banjar Ujung, Kelurahan Kesiman melakukan tindakan langsung ke lapangan. Dalam hal ini, Kepala Lingkungan Banjar Ujung bekerjasama dengan Bendesa Adat Kesiman dan

\footnotetext{
${ }^{6}$ Wawancara dengan Penggagas sekaligus bertindak sebagai Pengawas Yayasan Tukad Bindu, Bapak I Gusti Rai Ari Temaja, S.E, pada tanggal 10 Januari 2021.

${ }^{7}$ Wawancara dengan masyarakat setempat, I Nyoman Artha Wiguna, pada tanggal 10 Februari 2021.
}

empat banjar yang meliputi Banjar Ujung, Banjar Abian Nangka Kaja, Banjar Abian Nangka Kelod, dan Banjar Dukuh dengan membentuk Komunitas Kali Bersih atau Yayasan Tukad Bindu yang bertujuan untuk menata Sungai Bindu agar tidak tercemar dan tetap terjaga keasrian dan kelestariannya. ${ }^{8}$

Hal ini sejalan dengan teori peran yang merupakan aspek yang dinamis dalam kedudukan terhadap sesuatu. Dinamis dalam hal ini adalah suatu keterikatan empat Kepala Dinas tersebut, beserta Bendesa Desa Adat Kesiman dalam sebuah visi yang sama, dan yaitu untuk menata lingkungan Sungai Bindu agar tidak tercemar oleh limbah apapun itu sehingga tetap terjaga keasriannya. Penataan Sungai Bindu inilah yang berada dalam lingkup kedudukan terhadap sesuatu dalam teori peran yang dimaksud. Untuk mewujudkan visi tersebut maka dibuatlah Yayasan Tukad Bindu yang mengelola segala sesuatu terkait dengan pencemaran air di Sungai

${ }^{8}$ Shofyan Hadi Ramadhan, I Nyoman Sukma Arida, Karakteristik dan Makna Rekreasi Pengunjung dalam Leisure dan Recreation di Tukad Bindu Kota Denpasar, Jurnal Destinasi Pariwisata, Volume 8, No. 2, 2020, Hal 361. 
Bindu sehingga Sungai Bindu dapat digunakan oleh masyarakat sekitar termasuk pula dapat dijadikan sebagai ekowisata untuk khalayak umum.

Berdasarkan hasil wawancara yang dilakukan di Tukad Bindu dengan Bapak Ida Bagus Anom Parwatha, selaku Ketua Bidang Pendidikan di Yayasan Tukad Bindu terdapat dua faktor yang menyebabkan terjadinya pencemaran air di Sungai Bindu, yaitu faktor internal dan faktor eksternal. ${ }^{9}$ Faktor internal merupakan penyebab terjadinya pencemaran air secara alamiah yang disebabkan oleh alam itu sendiri, seperti proses pembusukan sampah-sampah organik dan peralihan fungsi lahan seperti terjadinya erosi di hulu sungai. Sedangkan faktor eksternal merupakan penyebab terjadinya pencemaran air yang berasal dari luar lingkungan yang disebabkan oleh tingkah laku manusia itu sendiri, seperti menjadikan Sungai Bindu sebagai tempat pembuangan limbah dan sampah rumah tangga dengan sembarangan.

${ }^{9}$ Wawancara dengan Ketua Bidang Pendidikan Yayasan Tukad Bindu, Bapak Ida Bagus Anom Parwatha, pada tanggal 10 Januari 2021.
Mengacu pada teori sistem hukum yang mengenai efektivitas penegakan hukum ada tiga unsur yaitu, unsur struktur, unsur substansi, dan unsur budaya hukum. Dimana jika penegakan hukum dalam menangani pencemaran air di Sungai Bindu tidak berjalan sesuai dengan substansi norma yang ada pada awig-awig maka budaya hukum di masyarakat masih saja acuh tak acuh terhadap penegakan hukum tersebut dan tidak akan berjalan dengan efektif. Hal ini mencerminkan disharmonisasi antara regulasi yang ada dengan perilaku masyarakat. Untuk menerapkan aturan yang efektif sekiranya aturan tersebut harus memuat maksud dan tujuan dari setiap hal yang dicitakan agar tidak menimbulkan multitafsir dimasyarakat terkait penanggulangan pencemaran di Sungai Bindu.

Dari data hasil wawancara dengan Bapak Ida Bagus Anom Parwatha, selaku Ketua Bidang Pendidikan di Yayasan Tukad Bindu, beliau menyebutkan bahwa ada beberapa upaya yang dilakukan oleh Yayasan Tukad Bindu untuk mencegah terjadinya pencemaran air, yaitu mengumpulkan tokoh-tokoh 
Jurnal Hukum Saraswati (JHS),Volume. 03, Nomor 02, (2021)

FAKULTAS HUKUM UNMAS DENPASAR

ISSN (Cetak) : 2715-758X ISSN (Online): 2720-9555

Doi:https://doi.org/10.36733/jhshs.v2i2

https://e-journal.unmas.ac.id/index.php/JHS

130

masyarakat, kepala lingkungan, dan kelian banjar untuk berdiskusi tentang cara merubah kebiasaan masyarakat agar tidak lagi membuang sampah dan limbah rumah tangga dengan harus dijaga kesuciannya yang disebut dengan Sad Kerthih yang sumbernya adalah Kutarakanda Purana Bangsul.Bagian dari Sad Kerthih tersebut yaitu:

sembarangan di wilayah Sungai Bindu. ${ }^{10}$ Selain upaya yang dilakukan oleh Yayasan Tukad Bindu, Desa Adat Kesiman pun tidak tinggal diam melihat permasalahan yang terjadi. Peran desa adat sangat dibutuhkan dalam menyelesaikan permasalahan pencemaran yang terjadi di Sungai Bindu. Dari data hasil wawancara dengan Bapak I Gede Anom Ranuara, S.Pd.,S.Sn.,M.Si, selaku Petajuh atau Wakil Bendesa Adat Desa Kesiman, beliau menyebutkan bahwa ada peran serta dari Desa Adat Kesiman yang sangat dibutuhkan dalam menjaga kelestarian lingkungan Desa Adat Kesiman yang bersinergi dengan Desa Dinas Kesiman, yaitu Desa Kesiman Kelurahan, Desa Kesiman Petilan, dan Desa Kesiman Kertalangu. Mengacu pada Lontar Kutarakanda Purana Bangsul yang disebutkan bahwa ada enam areal atau wilayah suci yang

\footnotetext{
${ }^{10}$ Wawancara dengan Ketua Bidang Pendidikan Yayasan Tukad Bindu, Bapak Ida Bagus Anom Parwatha, pada tanggal 10 Januari 2021.
}

1. Segara Kerthih (Laut), dimana laut itu merupakan tempat suci yang acuannya adalah air.

2. Giri Kerthih (Gunung), dimana gunung merupakan tempat suci yang acuannya adalah air. Gunung tersebut nantinya yang akan menerima air hujan.

3. Wana Kerthih merupakan upaya untuk melestarikan hutan yang bertujuan menampung air.

4. Ranu Kerthih merupakan upaya untuk menampung keluarnya air (bendungan).

5. Swi Kerthih merupakan sawah salwah yang berarti sal itu satu, wah itu air, yang dimana arti dari sawah salwah adalah hidupnya tergantung dari air yang mentransformasi hidupnya dari danau ke sawah itu adalah sungai.

6. Jagad Kerthih yang mengelola dan mengolah sawah itu. Dimana pada Jagad Kerthih ada peran binatang dan peran 
Jurnal Hukum Saraswati (JHS),Volume. 03, Nomor 02, (2021)

FAKULTAS HUKUM UNMAS DENPASAR

ISSN (Cetak) : 2715-758X ISSN (Online): 2720-9555

Doi:https://doi.org/10.36733/jhshs.v2i2

https://e-journal.unmas.ac.id/index.php/JHS

131

manusia. Peran binatang dalam menjaga kelestarian lingkungan, tersebut sebagai operasional bahwa masyarakat Desa Adat Kesiman pembajakan sawiah, sedangkan harus mengembangkan harmonisasi peran manusia sebagai dengan lingkungan sosialnya agar pelaksana.

Ketika berbicara tentang sungai yang harus di jaga kesuciannya, maka peran dari Desa Adat Kesiman sangat di perlukan saat ini. Mengacu terhadap Sad Kerthih diatas maka keteraturan sistem diatas harus dijaga dengan baik. $^{11}$ Selain peran serta yang mengacu pada Lontar Kutarakanda Purana Bangsul, Desa Adat Kesiman juga berperan pada aspek-aspek Tri Hita Karana yang bersumber pada ajaran agama Hindu, yaitu peran Desa Adat Kesiman pada bagian Parahyangan, dimana berperan dalam menyucikan areal Sungai Bindu dengan cara mengadakan upacara adat sebagai rasa terimakasih kepada Ida Sang Hyang Widhi Wasa, karena berkat aset yang ada di Sungai Bindu merupakan titipan dari Beliau, peran Desa Adat Kesiman pada bagian Pawongan, dimana desa adat mempunyai peran yang sangat penting

11 Wawancara dengan Petajuh atau Wakil Bendesa Adat Desa Kesiman, Bapak I Gede Anom Ranuara, S.Pd.,S.Sn.,M.Si, pada tanggal 25 Februari 2021.

tidak membuang sampah secara sembarangan, sedangkan peran Desa Adat Kesiman pada bagian Palemahanyaitu dengan menata ulang kawasan Sungai Bindu menjadi lebih tertata dan melakukan kegiatan bersihbersih disekitar wilayah Sungai Bindu agar tidak terjadinya pencemaran sungai. Selain itu ada langkah-langkah yang dilakukan oleh Desa Adat Kesiman yaitu membuat aturan-aturan adat/perarem, bekerjasama dengan tim kebersihan Kota Denpasar dan masyarakat untuk menjaga kelestarian lingkungan, memasang papan himbaun, dan bekerjasama dengan aparat penegak hukum.

Pada dasarnya ada 2 upaya untuk menanggulangi pencemaran sungai, yaitu secara teknis, dimana bersumber pada penanganan limbah secara baik dengan cara memilah atau mengolah sampah terlebih dahulu, dan non teknis, dimana menciptakan suatu peraturan-peraturan yang dapat merencanakan, mengatur dan mengawasi segala macam kegiatan 
yang dilakukan masyarakat setempat sehingga tidak terjadinya pencemaran. Mengacu pada teori perlindungan hukum menurut R. La Porta dalam Jurnal of Financial Economics, yang bertujuan untuk mengintegrasikan dan mengkoordinasikan berbagai kepentingan dalam masyarakat karena dalam lalu lintas kepentingan, perlindungan terhadap kepentingan tertentu hanya dapat dilakukan dengan cara membatasi berbagai kepentingan di lain pihak yang bersifat pencegahan dan bersifat hukuman. ${ }^{12}$

Berdasarkan hasil wawancara dengan Bapak Ida Bagus Anom Parwatha, selaku Ketua Bidang Pendidikan di Yayasan Tukad Bindu, beliau menyebutkan bahwa dalam upaya pencegahan pencemaran air yang terjadi di Sungai Bindu dilakukan dengan dua langkah yaitu langkah preventif dengan cara membuat aturan mengenai larangan membuang sampah di Sungai Bindu dan mengadakan sosialisasi terhadap masyarakat tentang tata cara menjaga dan melestarikan lingkungan, dan langkah represif dengan cara mengurangi, menekan,

\footnotetext{
${ }^{12}$ R. La Porta, Investor Prptection and Corparate govermance, Jurnal of financial Economics 58, 01 Januari, 2000.
}

dan menghentikan masyarakat yang masih membuang sampah dengan sembarangan, dan menjatuhkan sanksi terhadap masyarakat yang kurang mentaati aturan-aturan yang ada. ${ }^{13}$

\section{Simpulan dan Saran}

Berdasarkan dari uraian pembahasan diatas maka penulis menarik kesimpulan sebagai berikut:

Sungai Bindu tercatat dari tahun 1990 sampai dengan tahun 2010 telah terjadi pencemaran sungai yang diakibatkan oleh dua faktor. Diantaranya faktor internal dan faktor eksternal. Faktor internal merupakan penyebab terjadinya pencemaran air secara alamiah yang disebabkan oleh proses pembusukan sampah-sampah organik yang terdapat di sekitar lingkungan Sungai Bindu dan peralihan lahan yang terjadi di hulu Sungai Bindu, sedangkan faktor eksternal disebabkan oleh tingkah laku masyarakat sekitar Sungai Bindu yang masih tidak peduli atau acuh tak acuh terhadap adanya awig-awig dan aturan yang ada di Desa Adat Kesiman

13 Wawancara dengan Ketua Bidang Pendidikan Yayasan Tukad Bindu, Bapak Ida Bagus Anom Parwatha, pada tanggal 10 Januari 2021. 
Jurnal Hukum Saraswati (JHS),Volume. 03, Nomor 02, (2021)

FAKULTAS HUKUM UNMAS DENPASAR

ISSN (Cetak) : 2715-758X ISSN (Online): 2720-9555

Doi:https://doi.org/10.36733/jhshs.v2i2

https://e-journal.unmas.ac.id/index.php/JHS

133

tentang lingkungan, seperti membuang sampah dan limbah rumah tangga secara sembarangan, menggunakan bahan peledak atau racun untuk menangkap ikan.

Desa Adat Kesiman merupakan Desa Adat yang memiliki peranan penting dalam segala pembangunan di Desa Adat dan menjaga kelestarian sumber daya alam yang ada di wilayah Desa Adat Kesiman, salah satunya berperan dalam mencegah terjadinya pencemaran air yang terdapat di Sungai Bindu berdasarkan konsep Tri Hita Karana. Dalam hal ini Desa Adat Kesiman bersinergi dengan Desa Dinas Kesiman, yang dimana melakukan langkah-langkah seperti membuat aturan-aturan adat atau perarem tentang sanksi-sanksi yang akan dijatuhkan kepada masyarakat yang masih saja membuang sampah atau limbah rumah tangga ke wilayah Sungai Bindu dengan sembarangan, bekerjasama dengan tim kebersihan Kota Denpasar, Komunitas Peduli Sungai dan Yayasan Tukad Bindu, bekerjasama dengan masyarakat untuk menjaga kelestarian Sungai Bindu, memasang papan himbauan, dan bekerjasama dengan aparat penegak hukum untuk menyelesaikan masalah jika tidak dapat diselesaikan secara parum atau non litigasi.

Adapun saran yang dapat diberikan dari uraian pembahasan diatas yaitu mengajak semua lapisan masyarakat mulai dari anak-anak hingga dewasa, khususnya masyarakat Desa Adat Kesiman untuk saling menyadarkan diri dalam menjaga kebersihan dan kelestarian lingkungan dengan cara tidak lagi membuang sampah dan limbah rumah tangga dengan sembarangan, melakukan kegiatan bersih-bersih di Sungai Bindu secara berkala dan terus menerus guna menjaga dan melestarikan keasrian Sungai Bindu. Selain itu untuk Desa Adat Kesiman dalam pembuatan awigawig seharusnya tersurat dengan jelas bagaimana tentang cara pencegahan pencemaran lingkungan terutama pencegahan pencemaran air yang terdapat di Sungai Bindu. saya sebagai penulis mengharapkan bagi seluruh lapisan masyarakat yang berkunjung ke Sungai Bindu tetap bisa menjaga kebersihan dan mematuhi aturanaturan adat yang berlaku di Sungai Bindu agar tetap terjaga kelestariannya. 
Jurnal Hukum Saraswati (JHS),Volume. 03, Nomor 02, (2021)

FAKULTAS HUKUM UNMAS DENPASAR

ISSN (Cetak) : 2715-758X ISSN (Online): 2720-9555

Doi:https://doi.org/10.36733/jhshs.v2i2

https://e-journal.unmas.ac.id/index.php/JHS

134

\section{Daftar Pustaka}

\section{Buku}

Susriman, Prosiding Seminar Nasional

“Tanggung Jawab Pelaku Bisnis dalam Pengelolaan Lingkungan”.

\section{Jurnal}

Hadi Ramadhan Shofyan, Sukma Arida I Nyoman, 2020, Karakteristik dan Makna Rekreasi Pengunjung dalam Leisure dan Recreation di Tukad Bindu Kota Denpasar, Jurnal Destinasi

Pariwisata, Volume 8, No. 2.

La Porta R., 01 Januari 2000, Investor Prptection and Corparate governance, Jurnal of financial Economics.

Trisnawati Endah dan Ratriningsih Desrina, April 2017, Pengembangan Konsep Pariwisata Sungai Berbasis Masyarakat, Jurnal Aritektur KOMPOSISI, Volume 11, No.5.

Sulastriyono, Oktober 2008, Pembangunan Hukum Sumber Daya Air Sungai Yang Berbasis Undang-Undang No. 6 Tahun 2014 tentang Desa Adat.

\section{Peraturan Perundang-Undangan}

Undang-Undang No. 32 Tahun 2009 tentang Perlindungan dan Pengelolaan Lingkungan Hidup.

Undang-Undang No. 17 Tahun 2019 tentang Sumber Daya Air.

Undang-Undang No. 23 Tahun 1997 tentang Pengelolaan Lingkungan Hidup.

Kearifan Lokal: Peluang dan 
Jurnal Hukum Saraswati (JHS),Volume. 03, Nomor 02, (2021)

FAKULTAS HUKUM UNMAS DENPASAR

ISSN (Cetak) : 2715-758X ISSN (Online): 2720-9555

Doi:https://doi.org/10.36733/jhshs.v2i2

https://e-journal.unmas.ac.id/index.php/JHS

135

Peraturan Pemerintah No. 20 Tahun

1990 tentang Pengendalian

Pencemaran Air.

Peraturan Daerah Provinsi Bali No. 4

Tahun 2005 tentang Pengendalian

Pencemaran dan Perusakan

Lingkungan.

Peraturan Daerah Provinsi Bali No. 4 Tahun 2019 tentang Desa Adat Di

Bali. 